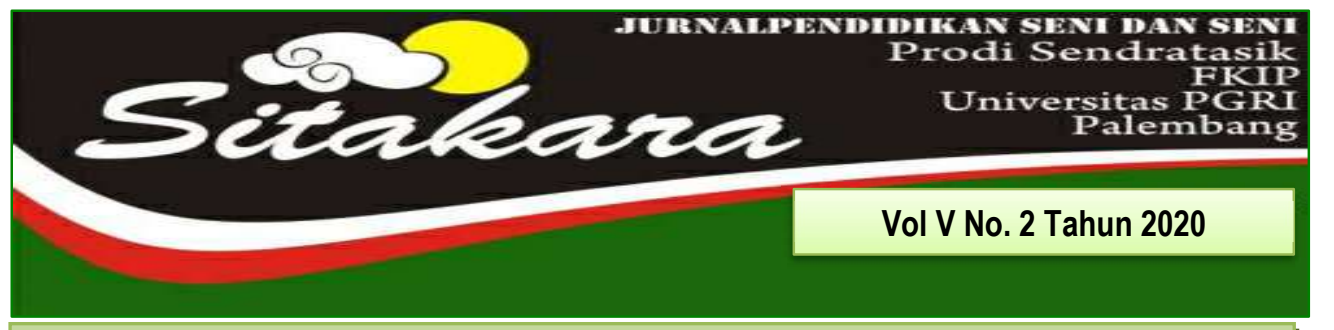

FUNGSI DAN MAKNA BHAJAN PADA UPACARA AGAMA HINDU DI KUIL SHRI MARIAMMAN KOTA MEDAN

(Agung Suharyanto, dkk)

KESENIAN SRANDUL DALAM UPACARA BERSIH DESA BULU KALURAHAN KARANGMOJO KECAMATAN KARANGMOJO KABUPATEN GUNUNGKIDUL YOGYAKARTA

(Supriyanto)

FUNGSI DAN MAKNA LAGU GUBANG DALAM UPACARA SIAR MAMBANG PADA MASYARAKAT TANJUNGBALAI

(Theo henry tua siagian ${ }^{1}$, pulumun p. Ginting ${ }^{2} \&$ wiflihani)

FUNGSI TARI MAPAK ADAT MUARA KUANG SEBAGAI TARI SAMBUT

(Nadia Rahma Aprilia', Dessy Wardiah², Treny Hera ${ }^{3}$ )

MAKNA SIMBOLIK RAGAM HIAS PADA RUMAH LIMAS PALEMBANG

(Ferri Hidayad ${ }^{1}$ Decky Kunian ${ }^{2}$ )

GAYA MUSIK SAHILIN DALAM KESENIAN MUSIK BATANGHARI SEMBILAN DI KOTA PALEMBANG

(Feri Firmansyah)

TRANSPOSISI TTI (TRANSFER, TRANSLATION, IMITATE) DALAM PEMBELAJARAN NOTASI MUSIK MELALUI SCORE CREATOR

(A Heryanto ${ }^{1}$ Dedy Firmansyah ${ }^{2}$ )

RASE TAK SERUPE MUSIK MELAYU TRADISI DENGAN PENGEMBANGAN MUSIK MODERN DALAM RUANG PERTUNJUKAN KOMPOSISI MUSIK NUSANTARA (Rio Eka Putra)

BENTUK SYAIR LAGU DALAM PERTUNJUKAN SYAROFAL ANAM DI PEDESTRIAN S UDIRMAN KOTA PALEMBANG

(Nofroza Yelli ${ }^{1}$ Deria Sepdwiko² ${ }^{2}$

"Betenun" Sebuah Wujud Proses Kreatif Mahasiswa Seni Pertunjukan Universitas PGRI PALEMBANG

(Nurdin $^{1}$ Naomi Diah Budi Setyaningrum ${ }^{2}$ ) 
DAFTAR ISI

FUNGSI DAN MAKNA BHAJAN PADA UPACARA AGAMA HINDU DI KUIL 1-15 SHRI MARIAMMAN KOTA MEDAN

(Agung Suharyanto, dkk)

KESENIAN SRANDUL DALAM UPACARA BERSIH DESA BULU KALURAHAN

$16-26$

KARANGMOJO KECAMATAN KARANGMOJO KABUPATEN GUNUNGKIDUL YOGYAKARTA

(Supriyanto)

FUNGSI DAN MAKNA LAGU GUBANG DALAM UPACARA SIAR MAMBANG 27-39 PADA MASYARAKAT TANJUNGBALAI

(Theo henry tua siagian ${ }^{1}$, pulumun $p$. Ginting ${ }^{2} \&$ wiflihani)

FUNGSI TARI MAPAK ADAT MUARA KUANG SEBAGAI TARI SAMBUT

40-52

(Nadia Rahma Aprilia', Dessy Wardiah², Treny Hera')

MAKNA SIMBOLIK RAGAM HIAS PADA RUMAH LIMAS PALEMBANG

53-61

(Ferri Hidayad ${ }^{1}$ Decky Kunian ${ }^{2}$ )

GAYA MUSIK SAHILIN DALAM KESENIAN MUSIK BATANGHARI SEMBILAN DI $\quad 62-76$ KOTA PALEMBANG

(Feri Firmansyah)

TRANSPOSISI TTI (TRANSFER, TRANSLATION, IMITATE) DALAM 77-85 PEMBELAJARAN NOTASI MUSIK MELALUI SCORE CREATOR (A Heryanto ${ }^{1}$ Dedy Firmansyah ${ }^{2}$ )

RASE TAK SERUPE MUSIK MELAYU TRADISI DENGAN PENGEMBANGAN MUSIK MODERN DALAM RUANG PERTUNJUKAN KOMPOSISI MUSIK NUSANTARA

(Rio Eka Putra)

BENTUK SYAIR LAGU DALAM PERTUNJUKAN SYAROFAL ANAM DI PEDESTRIAN SUDIRMAN KOTA PALEMBANG

(Nofroza Yelli ${ }^{1}$ Deria Sepdwiko ${ }^{2}$ )

"BETENUN" SEBUAH WUJUD PROSES KREATIF MAHASISWA SENI

$109-120$ PERTUNJUKAN UNIVERSITAS PGRI PALEMBANG

(Nurdin ${ }^{1}$ Naomi Diah Budi Setyaningrum ${ }^{2}$ )

86-95 


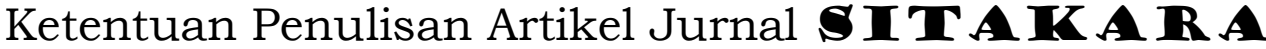

1. Naskah berbahasa Indonesia bertemakan Seni Budaya yang meliputi hasil penelitian pengajaran seni budaya, cabang seni, dan kebudayaan.

2. Naskah harus asli dan belum pernah dimuat dalam media lain. Naskah dapat berupa hasil penelitian perorangan atau kelompok.

3. Naskah ditulis dengan cara-cara yang sesuai dengan ketentuan penulisan artikel ilmiah menggunakan bahasa Indonesia yang baku, berupa ketikan, beserta soft line dalam CD-RW atau dengan mengirimkan email pada redaksi Jurnal SITAKA RA dengan alamat email: jurnalsitakarasendratasik@yahoo.com, spasi 1,5 jenis huruf Arrial Narrow ukuran 12, dengan panjang naskah antara 8-15 halaman pada kertas A4.

4. Artikel hasil penelitian memuat:

JUDUL

Nama Penulis

Abstrak

A. PENDAhuluan

B. METODE PENELITIAN

C. HASIL DAN PEMBAHASAN

D. SIMPULAN

5. Artikel kajian konseptual memuat:

JUDUL

Nama Penulis

Abstrak

PENDAHULUAN
: XXX (HURUF KAPITAL)

: (disertai jabatan dan institusi)

: (Bahasa Indonesia yang memuat 100150 kata diikuti kata kunci, dengan jenis huruf Arrial Narrow dan ukuran huruf 11 spasi tunggal serta dicetak miring)

: (Memuat latar belakang masalah, tinjauan pustaka secara ringkas, masalah penelitian dan tujuan penelitian)

: (Berisi simpulan)

\section{: XXX (HURUF KAPITAL)}

: (disertai jabatan dan institusi)

: (Bahasa Indonesia yang memuat 100150 kata diikuti kata kunci, dengan jenis huruf Arrial Narrow dan ukuran huruf 11 serta dicetak miring)

: (Memuat latar belakang masalah, tinjauan pustaka secara ringkas, 
Sub Judul

Sub Judul

SIMPULAN

DAFTAR PUSTAKA masalah penelitian dan tujuan

penelitian)

: Sesuai dengan kebutuhan (tanpa

numbering)

: (Berisi simpulan dan saran)

: (Berisi pustaka yang dirujuk dalam uraian naskah

6. Referensi sumber dalam teks artikel ditulis dengan menggunakan side note, contoh: (Jalalluddin, 1991:79); (Taufik, 2005;350); (Hamid dan Madjid, 2011:43). Sementara penulisan daftar pustaka disusun dengan ketentuan. Nama Pengarang. Tahun Terbit. Judul (dicetak miring). Kota Terbit: Nama Penerbit. Contoh: Koentjaraningrat. 2010. Manusia dan Kebudayaan Di Indonesia. Jakarta: Djambatan.

Daftar pustaka hanya memuat pustaka/sumber yang dirujuk dalam uraian dan disusun menurut abjad, tanpa nomor urut.

7. Naskah yang dimuat akan disunting kembali oleh redaksi tanpa mengubah isinya.

8. Naskah yang ditolak (tidak bisa dimuat) akan dikirim kembali ke penulis dengan pemberitahuan tertulis dari redaksi atau alamat email.

9. Penulis yang naskahnya dimuat akan mendapatkan 1 (satu) majalah nomor yang bersangkutan.

10. Contact Person: Treny Hera (085357344704) dan Mainur (081373165553). 


\title{
GAYA MUSIK SAHILIN DALAM KESENIAN MUSIK BATANGHARI SEMBILAN DI KOTA PALEMBANG
}

\author{
Oleh: \\ Feri Firmansyah \\ (FKIP Universitas PGRI Palembang) \\ Email: firmansyahferi1980@gmail.com
}

\begin{abstract}
ABSTRAK
Artikel ini merupakan hasil penelitian yang mengungkap gaya musik Sahilin dalam kesenian Musik Batanghari Sembilan di Kota Palembang, baik karya maupun penyajiannya. Penelitian dilandasi atas fenomena sahilinan yang sering dipersepsikan masyarakat Kota Palembang sebagai salah satu jenis seni musik tradisi, yang sebenarnya adalah seni Musik Batanghari Sembilan. Dari fenomena tersebut jelaslah bahwa karya-karya musik Sahilin dan penyajiannya memiliki gaya yang melekat, sehingga populer di tengah masyarakat penikmatnya dan muncul istilah sahilinan. Untuk mengetahui gaya musik Sahilin, pengumpulan data dilakukan dengan observasi, wawancara, dan dokumentasi. Selanjutnya penyajian data akan diuraikan secara deskriptif, melalui tahapan analisis bentuk dan struktur musik serta analisis komparatif untuk melihat gaya musik Sahilin. Hasil penelitian menunjukkan bahwa Sahilin dalam karya musiknya membuat lagu baru yang berbeda dari lagu yang lama. Selain itu, Sahilin membuat bentuk dan struktur lagu baru pada kesenian ini, yaitu menyajikan pantun dengan menggunakan satu kalimat lagu. Secara musikal Sahilin membuat pola-pola sajian musik yang variatif untuk mengurangi pertunjukan yang monoton. Spontanitas dalam berpantun dan dengan pantun-pantun yang jenaka dan sedikit porno, menjadi daya pikat tersendiri dalam setiap pertunjukan Sahilin.
\end{abstract}

Kata Kunci: Sahilin, Gaya musik, Musik Batanghari Sembilan

\section{A. PENDAHULUAN}

1. Latar Belakang

Sahilin merupakan salah satu pemain gitar tunggal dan penembang Musik Batanghari Sembilan di Kota Palembang yang masih eksis dan konsisten di jalurnya. Menurut M. Dasi'i sosok Sahilin bagi masyarakat Kota Palembang sangat dikenal bila berbicara soal Musik Batanghari Sembilan, sehingga muncul istilah sahilinan (Dasi'i, wawancara, 18 Agustus 2013). Kreativitas Sahilin dimulai dari 39 tahun yang lalu. Namun, sebelum itu bakat pria kelahiran tahun 1954 ini, dibentuk dari proses belajar bersama ayahnya Mad Sholeh. Selain belajar dari sang ayah, Sahilin juga tekun dalam menyimak variasi Musik Batanghari Sembilan pada setiap pertunjukan yang dimainkan oleh seniman-seniman terdahulu (Sahilin, wawancara, 10 Agustus 2013). Pantunpantun dipelajari Sahilin secara autodidak dari pengalamannya mendengar baik dari pertunjukan di kampungnya maupun dari radio. Dengan semangat belajar ini, Sahilin yang masih berumur belasan tahun, sudah menjadi 
seniman yang memilliki keterampilan menembang di kampungnya, yaitu Dusun Benawe Kecamatan Tanjung Lubuk Kabupaten Ogan Komering llir (OKI) (Sahilin, wawancara, 10 Agustus 2013).

Sahilin sangat populer di Kabupaten Ogan Komering llir sebagai seniman Musik Batanghari Sembilan. Salah satu ciri musik Sahilin terdapat pada pengolahan teks pantunnya yang kocak dan mengelitik (Sembilan, 2008: 70). Pada tahun 1973 Sahilin mengadu nasib di Kota Palembang, dengan bakat dan kemampuannya dalam memainkan gitar tunggal Musik Batanghari Sembilan, Sahilin mencoba tampil dari panggung ke panggung. Pada awal tahun 70-an berdiri sebuah studio rekaman di Kota Palembang, yaitu Palapa Record. Palapa Record khusus memproduksi lagu-lagu Sumatera Bagian Selatan waktu itu. Kaset-kaset rekaman Palapa Record banyak dijual oleh toko kaset bernama Gumarang. (Dasi'i, wawancara, 18 Agustus 2013).

Pada tahun 1975 Sahilin yang pada saat itu dikenal sebagai seniman Musik Batanghari Sembilan di Palembang, diberi kesempatan untuk rekaman di Palapa Record sekitar sepuluh album lebih. Ada empat album yang dapat ditemukan, yaitu album Bujang Buntu, Ratapan Mati Gadis, Indung-Indung Asli, dan album kompilasi yang di dalamnya terdapat Sahilin. Dalam rekamannya, Sahilin banyak berduet dengan Siti Rohmah yang pandai dalam pantun bersahut berbahasa Benawe (Sahilin, wawancara, 10 Agustus 2013). Selain berduet dengan Siti Rohmah, Sahilin pernah juga berduet dengan Cek Misah pada salah satu albumnya (Sahilin, wawancara, 10 Agustus 2013). Menurut M. Dasi'i kasetkaset dari album Sahilin sangat digemari masyarakat Palembang pada waktu itu (Dasi'i, wawancara, 18 Agustus 2013).

$$
\text { Selain mengembangkan }
$$

kreativitas melalui proses rekaman, Sahilin tetap tampil di berbagai acara sebagai seniman panggung. Pada tahun 1975 sampai 1980 akhir, jadwal tampilnya lima kali dalam seminggu. Namun, mulai tahun 1990 sampai sekarang Sahilin sudah jarang tampil (Sahilin, wawancara, 10 Agustus 2013). Hal ini seiring dengan makin banyaknya warna musik yang masuk di Kota Palembang sekitar tahun 1990, Musik Batanghari Sembilan semakin tergeser. Selan itu, Ahmad Bastari Suan juga 
mengatakan Palapa Record sudah tidak produktif lagi merekam sejak tahun 2000 (Ahmad, wawancara, 16 Agustus 2013). Namun Sahilin sering tampil untuk mewakili Musik Batanghari Sembilan. Hal ini dikarenakan Sahilin adalah salah satu seniman yang tetap konsisten pada Musik Batanghari Sembilan (Misral, wawancara, 20 Agustus 2013).

Sahiln juga dikenal oleh peneliti luar negeri, seperti Philip Yampolsky dari Ford Foundations. Philip Yampolsky pernah melakukan penelitian tentang kesenian ini. Sahilin dan Siti Rohmah direkam oleh Philip Yampolsky pada tanggal 3 Agustus 1994, untuk memainkan lagu Nasib Muare Kuang dan lagu Terang Bulan (Yampolsky, 1999: 28). Philip Yampolsky mengatakan bahwa sajian musik Sahilin unik dan variatif. Berbagai Penghargaan telah banyak diterima Sahilin. Puncaknya adalah penghargaan dari Departemen Kebudayaan dan Pariwisata RI bekerjasama dengan Asosiasi Tradisi Lisan, yaitu anugerah Maestro Seni Tradisi tahun 2007.

Fenomena kehidupan Sahilin dengan kreativitasnya sebagai seniman Musik Batanghari Sembilan merupakan hal yang menarik untuk diungkap.
Selanjutnya dibahas baik dari musikalitas dan virtuositasnya. Adapun alasan untuk melakukan penelitian ini yang pertama adalah ketertarikan pada fenomena seorang Sahilin yang sering disebut sebagai ikon Musik Batanghari Sembilan dengan istilah sahilinan. Selain itu Sahilin merupakan salah satu dari sebagian kecil masyarakat musik di Palembang yang tetap konsisten di jalur kesenian ini. Sahilin dapat dikatakan tetap aktif dan produktif dalam berkarya (Ahmad, wawancara: 16 Agustus 2013).

Yang kedua, berkembangnya kesenian tidak lepas dari peran seorang seniman yang konsisten pada kesenian tersebut. Oleh karena itu, penting bagi setiap peneliti untuk dapat menulis dan mengungkap keberadaan seniman yang mempunyai peranan dan kontribusi yang baik terhadap perkembangan kesenian tersebut (Kartodirjo, 1992: 76-77). Mengingat bahwa fokus penelitian ini adalah analisis gaya musik yang bertujuan mengungkap perihal kreativitas Sahilin dalam Musik Batanghari Sembilan, maka penelitian ini diberi judul "Gaya Musik Sahilin Dalam Kesenian Musik Batanghari Sembilan Di Kota Palembang (Kesenimanan Dan Gaya Musiknya)". 
2. Masalah Penelitian

Bagaimana gaya musik Sahilin dalam kesenian Musik Batanghari Sembilan Di Kota Palembang?

\section{Tujuan Penelitian}

Penelitian ini bertujuan untuk mengungkap gaya musik Sahilin dalam kesenian Musik Batanghari Sembilan, yaitu karya dan penyajiannnya.

\section{B. METODE PENELITIAN}

Untuk menjelaskan tentang gaya musik Sahilin penulis mengacu pada beberapa konsep gaya, yaitu menurut Edi Sedyawati dalam Sukerta, gaya seni merupakan bentuk yang tetap, serta senantiasa berulang dalam hal membentuk dan menyajikan karya seninya (Sukerta, 2004: 54-55). Secara eksplisit Waridi menambahkan bahwa, gaya dalam seni digunakan untuk menyebut ciri permainan atau ekspresi seorang seniman dalam memainkan instrumen atau melahirkan karya-karya ciptanya (Waridi, 2008: 38).

Pada penelitian ini Pengumpulan data akan dilakukan dengan observasi, wawancara, studi pustaka, dan dokumentasi. Data-data yang dikumpulkan selanjutnya akan dianalisis dengan mereduksi data, melakukan analisis bentuk dan struktur musik serta analisis komparatif untuk melihat gaya musik Sahilin sebagai seniman Musik Batanghari Sembilan. Hasil analisis data akan diuraikan secara deskriptif dengan mengutamakan uraian yang sistematis dan koheren.

\section{HASIL DAN PEMBAHASAN}

Pada bagian ini akan dipaparkan hal-hal yang terkait dengan Musik Batanghari Sembilan dan gaya musik Sahilin. Untuk itu agar penjelasan dapat terangkum dan tertata dengan baik, maka penjelasan kedua poin di atas akan menjadi satu kesatuan uraian. Musik Batanghari Sembilan merupakan kesenian musik yang terdiri dari sajian instrumen gitar tunggal dan/atau instrumen lainnya, dan vokal yang menyajikan lagu khas daerahnya, yang berisikan pantun-pantun berbahasa daerah dengan tema yang bervariasi, serta ditembangkan sesuai dialek dan/atau logat masing-masing daerah di Sumatera Selatan, di mana kesenian ini tumbuh dan berkembang khususnya di daerah Sumatera Selatan. Dalam kesenian Musik Batanghari Sembilan terdapat tiga unsur yang menjadi pokok bahasan, yaitu pantun, lagu dan struktur 
lagu, dan sajian instrumen. Tiga unsur tersebut akan diuraikan dan langsung di komparasikan dengan karya dan penyajian Sahilin dalam kesenan ini.

A. Pantun Gaya Sahilin

Pantun kesenian ini sama halnya dengan pantun melayu, yaitu sajak yang berbaris empat, dengan sanjak $a b$ ab (Fang, 2011: 556). Semua pantun Sahilin menggunakan bahasa Benawe, walaupun Sahilin hidup sebagai seniman di Kota Palembang. Walaupun menggunakan bahasa Benawe, masyarakat Palembang cukup mengerti maksud dari pantun Sahilin. Hal ini karena gaya bahasa dalam pantun Sahilin menggunakan bahasa ataupun percakapan sehari-hari. Sahilin juga bisa membuat pantun dengan menggunakan bahasa yang puitis, dengan arti dan makna yang dalam, seperti pada lagu Nasib Muare Kuang. Namun dalam pertunjukannya Sahilin lebih banyak menyajikan pantun-pantun dengan bahasa sehari-hari.

Pada satu acara di PAL TV, Sahilin menembangkan lagu Ribu-Ribu. Lagu ini dikenal melankolis oleh masyarakat Sumatera Selatan. Namun di dalam lagu tersebut Sahilin dan Siti Rohmah dengan pantun bersahutnya, menyuguhkan pantun-pantun dengan gaya bahasa sehari-hari untuk menyindir pengantin barunya. Suasana berubah ceria, ketika pantun tersebut disajikan. berikut pantunnya :

Hari ujan bedesah-desah, Singgah belindap bawah belimbing

Malam ini dapetlah susah, Nyamuk belage lawan kepinding (Hari hujan berdesah-desah, Singgah berteduh bawah belimbing Malam ini dapatlah susah, Nyamuk berkelahi lawan kepinding)

Singgah belindap bawah belimbing, Baék belindap bawah mengkudu

Nyamuk belage lawan kepinding, Itu cerite pengantèn baru

(Singgah berteduh bawah belimbing, Baik berteduh bawah mengkudu

Nyamuk berkelahi lawan kepinding, Itu cerita penganten baru) 
Gaya bahasa seperti di atas tetap dipertahankan oleh Sahilin dalam setiap penampilannya. Sampiran dan isi pantun selalu menggunakan bahasa sehari-hari, dengan tujuan agar mudah dipahami maksudnya (Sahilin, wawancara, 10 Agustus 2013). Seniman lain seperti Denali, dalam menyajikan pantunnya cukup sulit untuk di pahami. Berikut contoh pantun Denali dalam lagu seranting lidi.

Padi ampe seranting lidi, Ade kemayau masak di rumpun

Kami tige behadèng ini, Due di rantau suhang di duson

(Padi ampe seranting lidi, Ada kemayau masak di rumpun

Kami tiga bersaudara ini, Dua di rantau seorang di dusun)

Kiri gunung kanan gunung, Ume belukar bekandang tebu

Kiri bingong kanan bingong, Nerime kabar ndai wang prabu

(Kiri gunung kanan gunung,

Kebun belukar dipagar tebu

Kiri bingung kanan bingung,

Menerima kabar dari orang Prabu)
Dalam berpantun hal yang paling diutamakan Sahilin adalah spontanitas. Walaupun menembangkan pantun secara spontan, Sahilin tetap menjaga kaidah berpantun yang baik dan benar dalam kesenian ini. Abraham Maslow mengatakan, bahwa spontanitas ditandai dengan perilaku kesederhanaan dan kewajaran, serta oleh kurangnya sikap yang dibuat-buat atau memaksakan efek (Maslow, 1994:11). Hal inilah yang membuat Sahilin berbeda dengan seniman lainnya saat ini, seperti Arman dan M. Dasi'i yang menyajikan pantun sesuai pesanan. Berikut contoh pantun M. Dasi'i :

Muare Kuang enam belas duson, Lime di Kuang sebelas di ungan Duson Muare Kuang mintak di suson, Banyak kekurangan serbe ketinggalan

(Muare Kuang enam belas dusun, Lima di Kuang sebelas di Ungan

Dusun Muare Kuang Minta di susun, Banyak kekurangan serba ketinggalan)

Pantun di atas dibuat oleh $\mathrm{M}$. Dasi'i atas permintaan Camat Muare Kuang, yang disajikan pada saat Gubernur Sumatera Selatan datang ke 
Daerah Muare Kuang (Dasi,i, wawancara, 18 Agustus 2013). Dalam pantun tersebut M. Dasi'i menyampaikan aspirasi masyarakat untuk perbaikan $\mathrm{di}$ daerahnya. Sahilin tidak pernah melakukan hal tersebut, Sahilin selalu berpantun sesuai dengan keinginannya. Sahilin mengatakan bahwa apa yang dirasakan dan dipikirkan semuanya bisa dipantunkan (Sahilin, wawancara, 10 Agustus 2013). Oleh karena itu, banyak pantun baru yang dibuat Sahilin. Spontanitas dalam berpantun, tidak serta merta dapat dilakukan dengan mudah. Pengalamannya menembang yang konsisten dengan pantun bersahut, merupakan faktor yang mendukung hal tersebut.

Sampai saat ini Sahilin selalu berduet jika tampil. Sahilin juga mencari rekan duetnya yang spontan dalam berpantun. Sahilin mencari rekan duetnya berpantun tidak dengan menghafal atau membaca buku. Menurut Sahilin hal tersebut akan membuat pertunjukannya kaku dan terbatas pantunnya. Sahilin dan Siti Rohmah selalu berpantun secara spontan. Sedangkan M. Dasi'i, Arman, Sasman Hadi selalu menulis pantunnya terlebih dahulu, setelah itu dihafal dan baru ditembangkan.

Sahilin juga dikenal dengan pantun-pantun jenaka yang diawali dengan munculnya album Bujang Buntu. Dalam album tersebut terdapat juga lagu lain yang pantunnya jenaka, yaitu lagu Kucing Kurus Mandi Di Papan dan lagu Incang-Incang. Sahilin memang tidak ingin pantunnya yang sedih-sedih saja. Sahilin mengatakan dalam bahasa Palembang, "dak maju mon nak sedihsedih bé" (tidak berkembang kalau hanya sedih-sedih saja) (Sahilin, wawancara, 10 Agustus 2013). Dari pernyataan tersebut Sahilin sudah bisa membaca pasar ataupun konsumennya di Palembang. Palembang memang terkenal dengan budaya besak kelakar. Besak kelakar sama dengan orang yang senang bersenda gurau, bahkan dalam lagu Bujang Buntu Sahilin dan Siti Rohmah sudah menyebut istilah besak kelakar tersebut. Berikut pantun jenaka Sahilin :

Nak kemane parang panjang, Pegi menebang batang jehèng

Banyaklah nian dengan diam, Nonton Siti tekurus kerèng (Mau ke mana parang panjang, Pergi menebang batang jengkol 
Banyaklah benar kamu diam, Nonton Siti yang kurus kering)

Alangkah lurus lah kau papan, Ndak dibuat lantai jerami

Sahilin kurus bukan dék makan, Ibarat budak kurang pétamén

(Alangkah lurus kau papan, Mau dibuat lantai jerami

Sahilin kurus bukan tidak makan, lbarat anak kurang vitamin)

\section{B. Sajian Instrumen Gaya Sahilin}

Saat ini ada dua bentuk sajian instrumen pada kesenian ini, yaitu format ansambel dan gitar tunggal.

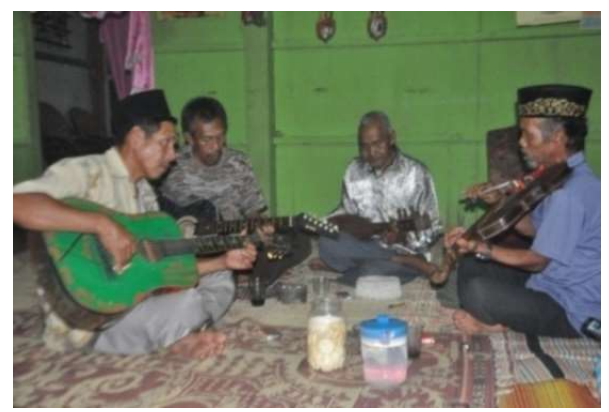

Gambar 1. Sajian Instrumen Dengan Gitar, Biola, Gambus

(Foto, Feri: 2014)

Seniman di Pulau Beringin menamakan sajian instrumen seperti ini adalah rejung betebah, yang berarti bermain dan menembang bersamasama. Dalam format ini setiap penyaji memainkan peranannya masing-masing sebagai pengiring. Gitar membentuk pola irama musiknya, dengan pola bas pada senar atas, yang selalu diulang-ulang. Selain itu, gitar dan gambus juga menyajikan melodi vokal, yang dimainkan pada senar bawah, dengan pola ritme yang berbeda dari melodi vokal, dan biola memainkan lagu. Selanjutnya dalam menembang dilakukan secara bergantian, masingmasing menembangkan dua sampai tiga pantun dengan bahasa daerah Pulau Beringin.

Bentuk sajian yang paling populer saat ini adalah gitar tunggal. Setiap daerah di Sumatera Selatan menggunakan gitar tunggal dalam kesenian ini. Menurut Ahmad Bastari Suan, gitar tunggal ini sudah ada sebelum tahun 1940-an. Namun belum ada data pasti yang menunjukkan tahun berapa mulai digunakan, dan siapa yang mempopulerkan ini (Ahmad, wawancara, 16 Agustus 2013). Sahilin selalu menggunakan bentuk sajian gitar tunggal dalam setiap penampilannya. Hal tersebut dilakukannya secara konsisten sampai saat ini.

Dalam bermain gitar, secara teknis kecepatan serta akurasi tangan kanan dan tangan kiri Sahilin dalam 
memetik dan menekan setiap senar gitar, cukup memenuhi standar. Untuk lagulagu yang cepat dan lambat Sahilin melakukannya dengan baik. Setiap penampilannya untuk program televisi, Sahilin selalu tampil secara live dalam memainkan gitarnya. Belum ditemukan penampilan Sahilin yang menggunakan sistem dabing. Berbeda dengan seniman lain yang diamati, seperti Ribuanata, Alex Munandar, Arman, dalam satu program televisi menggunakan sistem dabing untuk sajian gitarnya.

Sahilin juga dapat memainkan sajian gitar tunggal sambil menembangkan pantun-pantunnya. Khususnya di Palembang, jarang sekali seniman yang bisa melakukan hal tersebut. Seniman Musik Batanghari Sembilan di Palembang seperti Alex Munandar dan Ribuanata, dalam setiap penampilannya hanya memainkan sajian gitar tunggalnya saja. Selain itu M. Dasi'i yang seumur dengan Sahilin, hanya menembang saja. M.Dasii mengatakan bahwa ia pernah mencoba memainkan gitar tunggal, namun pada saat menembang jarinya berhenti memetik gitar (Dasiï, wawancara, 18 Agustus 2013). Butuh konsentrasi yang tinggi untuk dapat memainkan gitar tunggal sambil menembang, gitar tunggal bukan hanya sekedar memainkan pola bas, namun di senar bawah pola melodi vokal juga dimainkan. Dalam penampilan Sahilin, kemampuan seperti inilah yang membuat banyak orang simpati, dengan matanya yang buta Sahilin mampu memainkan gitar sekaligus menembangkan pantun-pantunnya.

Pola melodi pada permainan gitar Sahilin sangat variatif, jika dibandingkan dengan pemain gitar tunggal lainnya. Hasil analisis lagu Nasib Muare Kuang, Bujang Buntu, Ratapan Mati Gadis, Sahilin memainkan pengajak dan jembatan sajian gitar yang bervariasi untuk pola melodinya. Bahkan pola melodi pengajak berbeda dengan sajian gitar pada lagu. Pada setiap bait pantun, jembatan sajian gitar untuk frase lagu, kalimat lagu, dapat berbeda pola melodinya, dan terkadang merubah sukat dalam satu birama untuk mencukupi variasi melodinya.

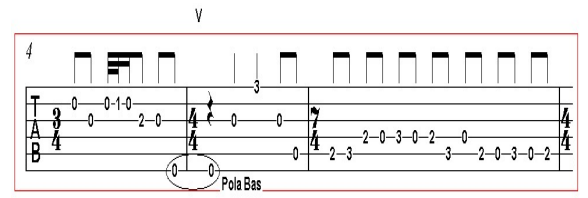

Notasi 1. Sajian Gitar Tunggal Sahilin Pada Lagu Nasib Muare Kuang 
Pada notasi di atas terlihat pola perminan gitar yang variatif dilakukan Sahilin. Pertama, Sahilin menyajikan gitar tunggal pada tiga sukat yang berbeda, yaitu 3/4, 4/4, dan 7/4. Kedua, sahilin membuat sajian gitar yang mengunakan pola bas pada sukat 4/4, dan mengunakan pola melodi tanpa pola bas pada sukat $7 / 4$. Selanjutnya pada notasi di bawah, Sahilin menggunakan pola melodi tanpa pola bas untuk mengiringi lagu. Sahilin membuat pola melodi yang mengiringi lagu, sesuai dengan skala lagu. Sehingga melodi lagu dan sajian gitarnya akan tetap harmonis.

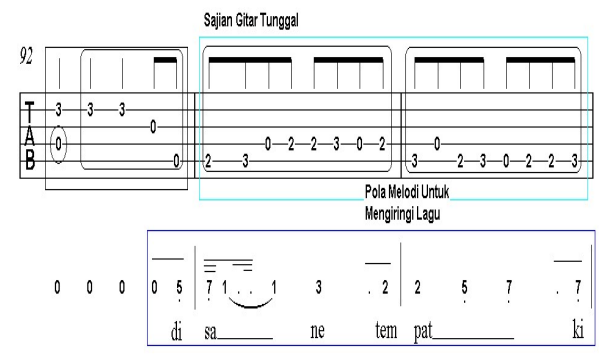

Notasi 2. Sajian Gitar Tunggal Sahilin

Pada Lagu Nasib Muare Kuang
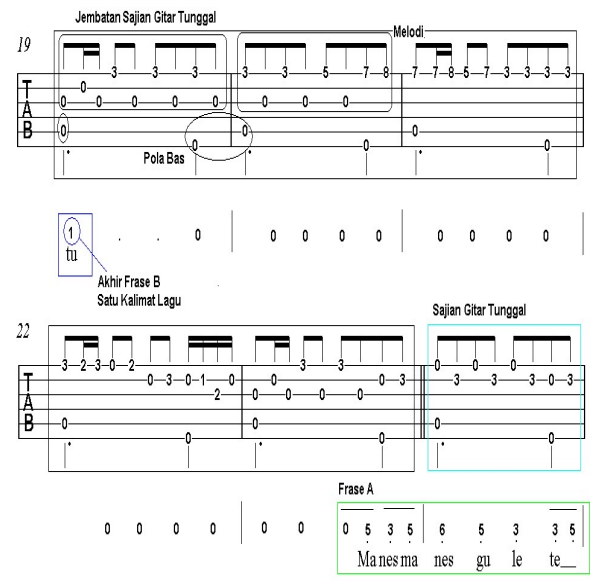

Notasi 3. Sajian Gitar Tunggal Sahilin

Pada Lagu Bujang Buntu

Pada notasi di atas, Sahilin membuat jembatan sajian gitar tunggal berbeda dengan sajian gitar tunggal pada lagu. Sahilin membuat pola melodi yang berbeda dengan melodi lagunya. Pada lagu Bujang Buntu tersebut, jembatan sajian gitar tunggal di atas berbeda dengan jembatan sajian gitar tunggal lainnya. Hal tersebut di atas jarang sekali dilakukan oleh pemain gitar tunggal lainnya. Rata-rata seniman menggunakan pola gitar tunggal di bagian pengajak untuk sajian gitar pada lagu. Selanjutnya untuk jembatan sajian gitar, rata-rata seniman hanya mengulangi pola-pola yang sudah dimainkan pada bait pertama. Pola-pola seperti ini membuat penyajian Musik Batanghari Sembilan menjadi monoton, seperti Pola gitar tunggal yang disajikan oleh Ribuanata pada lagu Tige Serangkai. Ribuanata memainkan pengajak seperti sajian gitar pada lagunya. Selain itu, jembatan juga diambil dari pola yang dimainkan pada bagian pengajak. Berikut notasinya. 


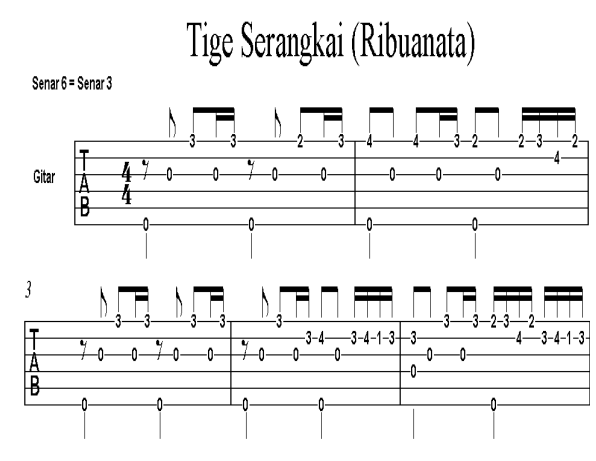

Notasi 4. Sajian Gitar Lagu Tige

Serangkai (Ribuanata)

Membuat pola-pola gitar tunggal yang variatif, memang dilakukan Sahilin untuk mengurangi penyajian yang monoton. Sahilin mengatakan bahwa lagu tersebut selalu diulang-ulang pada setiap bait pantunnya, oleh karena itu pantun dan sajian gitarnya harus menarik (Sahilin, wawancara,10 Agustus 2014). Pernyataan ini menjadi konsep dasar Sahilin dalam mengembangkan Musik Batanghari Sembilan. Sahilin sadar dan paham bahwa dengan penyajian yang monoton akan menimbulkan kejenuhan. Sahilin menambahkan bahwa pola-pola permainan gitar yang variatif tersebut, dibuatnya secara spontan (Sahilin, wawancara, 28 Agustus 2013). Hal ini menunjukkan kemapanan Sahilin dalam bermain gitar tunggal pada kesenian ini.

\section{Lagu Dan Struktur Lagu}

Istilah lagu dalam kesenian ini berbeda dengan pengertian lagu sebagai sebuah komposisi. Hal ini karena lagulagu pada kesenian ini dikembangkan dari senandung khas di Sumatera Selatan. Selain itu, setiap lagu dapat digunakan untuk menembangkan pantun yang berbeda-beda. Tidak ada ketentuan bahwa lagu tersebut harus disajikan dengan teks pantun yang khusus (Sahilin, wawancara, 10 Agustus 2013).

Menurut M. Dasi'i dan Ribuanata, lagu-lagu ini berasal dari senandung khas daerah tersebut, yang dikembangkan oleh seniman terdahulu, untuk menyajikan pantun-pantun tersebut dalam Musik Batanghari Sembilan (Ribuanata, wawancara, 23 April 2014). Hal tersebut sejalan dengan penjelasan Liaw Yock Fang, bahwa pantun adalah senandung atau puisi rakyat yang dinyanyikan, sampai sekarang pantun masih dinyanyikan. Abdullah Munsyi dalam pelayaran ke Kelantan mencatat cara-cara pantun dinyanyikan (Fang, 2011: 556). Selain lagu yang lama seperti lagu "Nasib", lagu "Tige Serangkai", lagu "Merilungan", lagu "Ribu-Ribu", lagu "Antan Delapan", saat ini sudah banyak lagu yang baru. Ada lagu yang terpengaruh dari lagu melayu 
yang populer di Malaysia, seperti lagu "Kucing Kurus Mand Di Papan" karya Sahilin. Selain itu, ada juga lagu dari pengembangan lagu-lagu yang lama, seperti lagu "Ratapan Mati Gadis" karya Sahilin, yaitu pengembangan dari lagu "Ribu-Ribu" (Sahilin, wawancara, 10 Agustus 2013).

Penyajian lagu pada kesenian ini hampir semua sama yaitu merupakan bentuk satu bagian, yang di dalamnya terdapat kalimat dan frase lagu. Berikut struktur lagu pada sajian Musik Batangahari Sembilan.

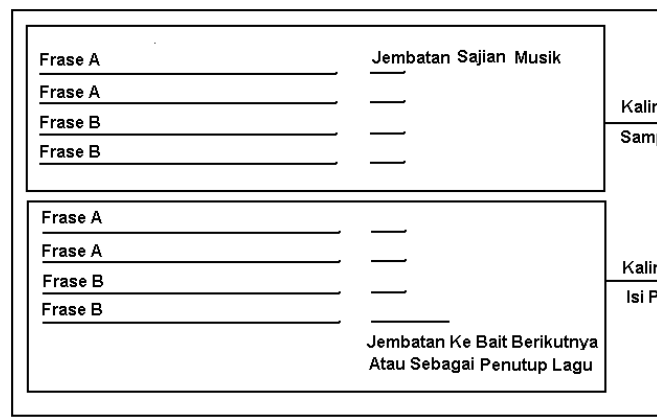

Diagram 1. Struktur Lagu Yang Pertama Strutktur lagu yang pertama merupakan bentuk yang komprehensif dalam kesenian ini. Namun ada struktur lain yang lebih sederhana. Struktur lagu yang umum digunakan berikutnya diambil dari lagu Gunung Daes yang disajikan oleh Zainudin, seperti berikut :

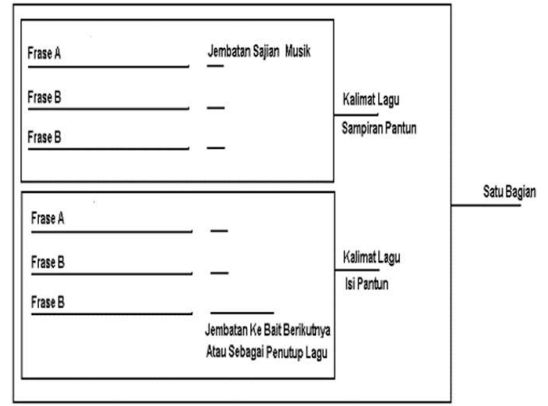

Diagram 2. Struktur Lagu Yang Kedua Struktur lagu lain diambil dari lagu Jurai Rampean oleh Imhadi, seperti berikut :

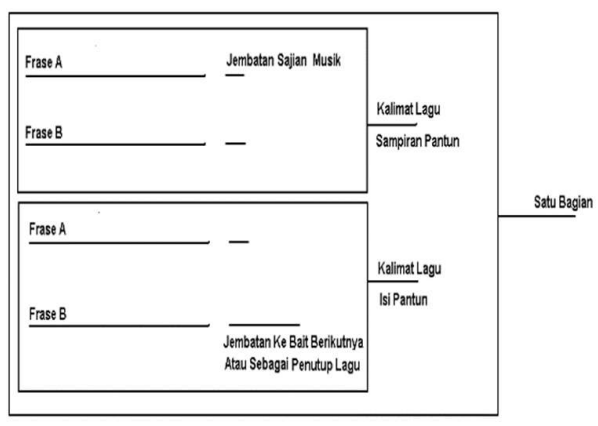

Diagram 3. Struktur Lagu Yang Ketiga Selanjutnya struktur lagu keempat dari lagu Ribu-Ribu yang disajikan M. Dasi'I seperti berikut:

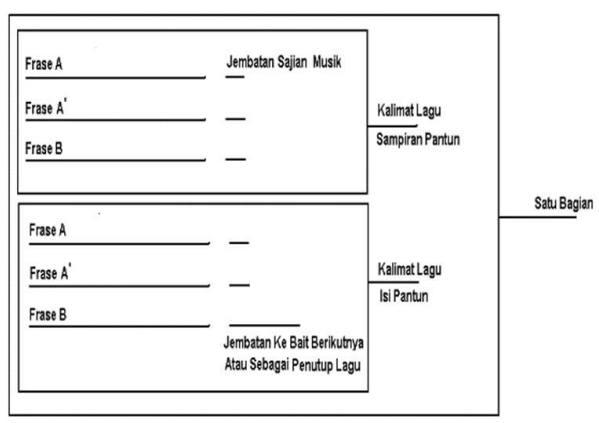

Diagram 4. Struktur Lagu Yang

Keempat 


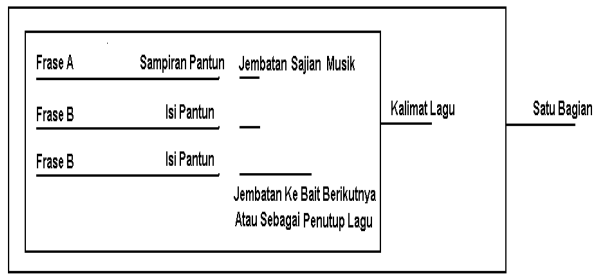

Diagram 5. Struktur Lagu Bujang Buntu Karya Sahilin

Struktur lagu di atas merupakan lagu Bujang Buntu Karya Sahilin. Alex Munandar mengatakan bahwa lagu Bujang Buntu bukan lagu lama yang sudah pernah ada, tapi lagu ini memang ciptaan Sahilin (Alex, wawancara, 19 Agustus 2013). Terlihat jelas bahwa Sahilin membuat struktur lagu yang baru yang berbeda dar struktur lagu yang lama. Sahilin menembangkan pantun dengan satu kalimat lagu.

Jika dilihat dari lagu, Sahilin memiliki kreativitas mengolah lagu-lagu lama, seperti lagu Ratapan Mati Gadis merupakan pengembangan dari lagu Ribu-Ribu, yang disajikan M.Dasi'i. Pada pada frase $A$, kedua lagu memilliki kesamaan secara musikal, baik di awal dan akhir frase. Pada frase $B$ secara musikal juga memiliki kesamaan pada akhir frasenya. Namun Sahilin mengembangkan melodi lagu Ribu-Ribu di tengah-tengah frase B. Pada lagu Ribu-Ribu satu kalimat lagu hanya berisi sampiran, sedangkan pada lagu Ratapan Mati Gadis satu kalimat lagu membawakan satu bagian, yaitu sampiran dan isi sekaligus.
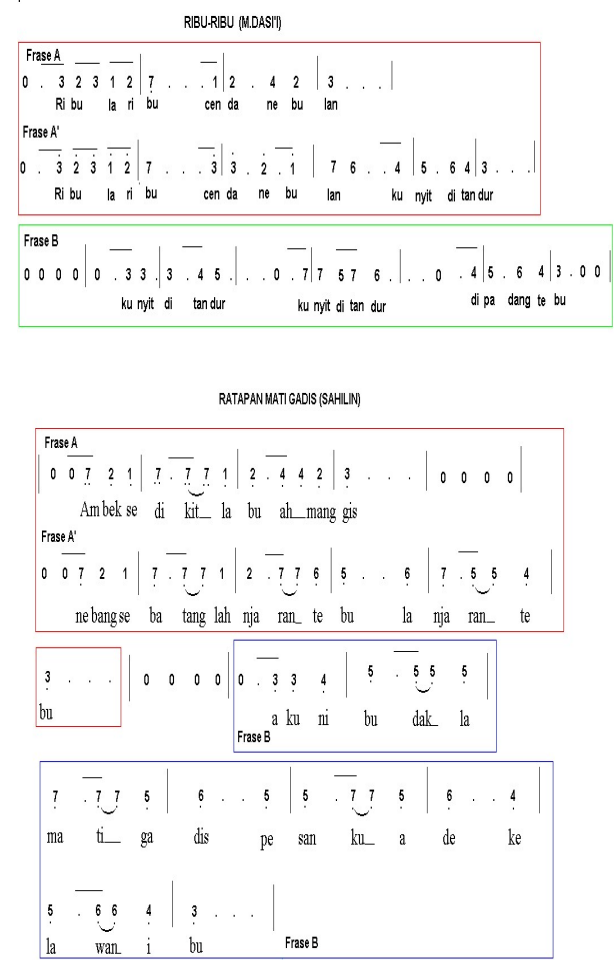

Notasi 5. Lagu Ribu-Ribu (M.Dasi'i) Dan Lagu Ratapan Mati Gadis (Sahilin)

Selain mengembangkan lagu yang sudah ada, Sahilin juga membuat lagu baru. Lagu Bujang Buntu, Kucing Kurus Mandi Di Papan, Tekukur Terang Bulan, dan Ape Gune Besepan Panjang, merupakan lagu baru yang dibuat Sahilin. Lagu-lagu tersebut secara musikal berbeda dengan lagu-lagu lama, 
seperti lagu Nasib, Ribu-Ribu, dan Antan Delapan.

\section{SIMPULAN}

Dari hasil penelitian dan pembahasan yang telah diuraikan, dapatlah ditarik beberapa simpulan yang menunjukkan gaya musik Sahilin dalam kesenian Musik Batanghari Sembilan. Pertama, pantun-pantun Sahilin selalu menggunakan bahasa sehari-hari agar mudah dipahami pendengarnya. Selain itu, pantun-pantun jenaka dan porno yang dibawakan secara spontan merupakan daya tarik pada setiap penampilannya yang jarang dilakukan oleh seniman lainnya. Kedua, sajian gitar tunggal Sahilin menampilkan pola-pola melodi yang variatif, yaitu pola-pola melodi yang berbeda dengan lagunya. Selain itu, Sahilin dapat memainkan gitar tunggal dengan sambil menembang yang jarang dilakukan oleh seniman lainnya. Ketiga, Sahilin membuat lagu baru dan struktur lagu yang baru pada penyajiannya, yaitu menembangkan satu baitu pantun dengan satu kalimat lagu. Hal ini, dlakukan Sahilin pada saat membuat lagu Bujang Buntu, Kucing Kurus Mandi Di Papan, dan lagu IncangIncang. Selain membuat lagu yang baru dengan struktur lagu yang baru, Sahilin juga mengembangkan lagu-lagu lama dengan membawakannya dengan struktur lagu yang berbeda dari lagu lama tersebut, serta mengembangkan frase lagu lama tersebut, sehingga lagu lama tersebut menjadi lebih variatif dan terkesan lebih ringkas. Hal ini dilakukan Sahilin dalam membawakan lagu Riburibu yang dikemasnya dalam lagu berjudul Ratapan Mati Gadis.

\section{DAFTAR PUSTAKA}

Fang, Liaw York. 2011. Sejarah Kesusastraan Melayu Klasik. Jakarta: Yayasan Pustaka Obor Indonesia.

Kartodirjo, Sartono. 1992. Pendekatan IImu Sosial Dalam Metodologi Sejarah. Jakarta: PT. Gramedia Pustaka Utama.

Maslow, Abraham H. 1994. Motivasi dan Kepribadian, Teori Motivasi dengan pendekatan Hierarki Kebutuhan Manusia. Jakarta: PT. Pustaka Binaman Pressindo.

Sembilan, Kobar. 2008. Sastra Tutur Sumatera Selatan, Peran dan Fungsinya (OKI dan MUBA). Sumatera Selatan: Dinas Pendidikan Provinsi Sumatera Selatan. 
Sukerta, Pande Made. 2004. "Perubahan Dan Keberlanjutan Dalam Tradisi Gong Kebyar : Studi Tentang Gong Kebyar Buleleng". Denpasar: Disertasi Program Pascasarjana Universitas Udayana Denpasar.

Waridi. 2008. Gagasan dan Kekaryaan Tiga Empu Karawitan, Pilar Kehidupan Karawitan Jawa Gaya Surakarta 1950-1970-an, Ki Martapengrawit, Ki Tjakrawasita, Ki Nartasabda. Bandung: Etnoteater Publisher.

Yampolsky, Philips. 1999. Music Of Indonesia Vol. 20 : Indonesian Guiars. Recorded, compiled, and annotated by Philip Yampolsky. 32-page booklet. 73 minutes: SFW 40447.

\section{DAFTAR NARASUMBER}

Alex Munandar (38), Seniman Musik Batanghari Sembilan, Jalan Dwikora II no. 99 Palembang.

M. Dasi'i Husin (59), Seniman Musik Batanghari Sembilan, Jalan Let. Murod Talang Ratu Lrg. Sakura no. 1226 rt. 25 rw. 58.

Misral (45), Seniman Musik Daerah Palembang dan Dosen Musik Jurusan Kesenian FKIP Univ. PGRI Palembang, Jalan Sukarela-Batujajar Irg. Sejambu I rt. 18 rw. 07 Sukarami Palembang.

Ribuanata (44), Seniman Musik Batanghari Sembilan, Perumahan Polygon Bukit Baru.

Sahilin (59), Seniman Musik Batanghari Sembilan, Lrg. Kedukan II Kelurahan 36 llir Kecamatan Gandus. 